(1991) Quantitative turbidimetric assay for determining myoglobin evaluated. Annals of Clinical Biochemistry 28, 474-479.

5. Collinson P.O., Rosalki S.B., Kuwana T., Garratt H.M., Ramhamadamy E.M., Baird I.M. \& Greenwood T.W. (1992) Early diagnosis of acute myocardial infarction by CK-MB mass measurements. Annals of Clinical Biochemistry 29, 43-47.

6. Kilpatrick W.S., Wosornu D., McGuinness J.B. \& Glen A.C.A. (1993) Early diagnosis of acute myocardial infarction: CK-MB and myoglobin compared. Annals of Clinical Biochemistry 30, 435-438.

7. Drexel H., Dworzak E., Kirchmair W., Milz M.M., Puschendorf B. \& Dienstl F. (1983) Myoglobinaemia in the early phase of acute myocardial infarction. American Heart Journal 105, 642-651.

\section{An unexpected foreign body: a case of external opthalmomyiasis}

An 11-year-old boy recently presented to the Accident and Emergency (A\&E) Department of the Birmingham and Midland Eye Hospital complaining that a fly had hit his right eye and felt as if it was still in the eye. This had occurred the previous day, at the end of a 2-week holiday in Rhodes. On eversion of the upper lid four moving pin head sized larvae were seen on the inflamed conjunctiva (Fig. 1). The larvae were removed with a cotton bud and the boy was given chloramphenicol drops to treat any secondary infection. The discomfort had settled on review 2 days later.

The larvae were identified by Dr Anderson of The University of Birmingham, as the first instar larvae of Oestrus ovis, the sheep nostril fly. Female Oestrus ovus flies are larviparous, usually squirting their larvae up sheep nostrils whilst in flight. Occasionally their larvae go astray.

The invasion of tissues by larvae is called myiasis. This particular case is an example of external ophthalmomyiasis. The larvae can burrow into the eyelid, conjunctiva and lacrimal ducts using both the spines on their eleven body segments and their large oral hooks. Rarely, the larvae may penetrate the eyeball causing blindness. ${ }^{1}$

Oestrus ovis are found in North Africa, Asia and the Mediterranean. $^{2}$ Although, three cases are thought to have occurred in England. ${ }^{3}$ Previously only one case has been reported as being 'imported' to England. ${ }^{4}$ Bearing in mind the prevalence of travel to the Mediterranean nowadays, such conditions should be looked out for and one should remember to check under the eyelid.

\section{S.J. TALKS}

Birmingham and Midland Eye Hospital, Churgh Street, Birmingham B3 2NS

\section{REFERENCES}

1. Rakusin W. (1970) Ocular myiasis interna caused by the sheep nasal bot fly (Oestrus ovis). South African Medical Journal 44, 1155-1162.

2. Reid A.M. (1972) Ophthalmology in the tropics. In: Manson's Tropical Diseases. (eds C. Wilcocks \& P.E.C. Manson-Bahr), pp. 829-890. Bailliere Tindall, London.

3. Stevens J.D., McCartney A.C.E. \& Howes R. (1991) Oestrus ovis ophthalmomyiasis acquired in the U.K.: case report and scanning electron microscopic study. British Journal of Ophthalmology 75, 702-703.

4. Wong D. (1982) External ophthalmomyiasis caused by the sheep bot Oestrus ovis L. British Journal of Ophthalmology 66, 786-787.

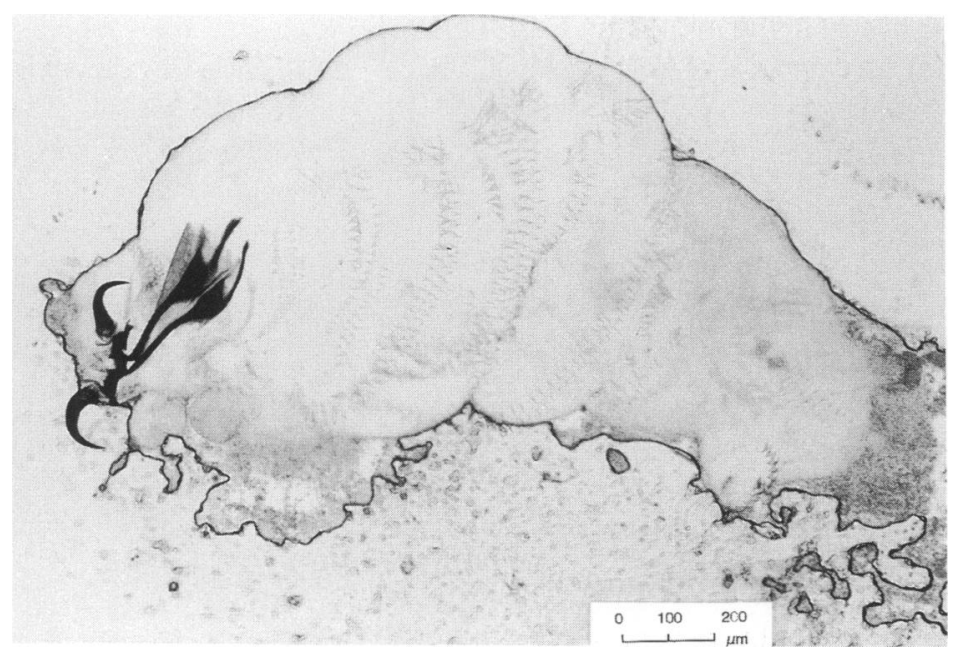

Fig. 1. One of the Oestrus ovis following removal from the patient's eye. 